\title{
Studies in Infantile Marasmus. IV. Impairment of Immunologic Responses in the Marasmic Pig
}

\author{
Vigente López ${ }^{[66]}$, Starkey D. Davis, and Nathan J. Smith \\ Department of Pediatrics, University of Washington School of Medicine, Scattle, Washington, USA
}

\begin{abstract}
Extract
We investigated the immunologic responses in an experimental model, the marasmic piglet. Two litters of miniature piglets of the Pitman Moore strain [46] were divided into two groups with five of the animals given normal diet and eight subjected to dietary restriction. The dietary intake of the experimental piglets was restricted to prevent further significant weight gain after the age of 35 days. The experimental animals displayed a well developed characteristic picture of severe undernutrition after 3 months of dietary restriction. Concentrations of immunoglobulins $\mathrm{G}$ and $\mathrm{M}$ ( $\mathrm{IgG}$ and $\operatorname{IgM}$ ) in both experimental and control pigs were similar. Antibody titers against erythrocyte A-antigen of experimental pigs were consistently lower (Table IV). Antibody responses after immunization to tetanus toxoid, sheep erythrocytes, and bacteriophage $\phi \mathrm{X} 174$ were remarkably similar in both groups (Tables V and VI). The experimental animals had a delay in appearance of $\operatorname{IgG}$ antibody after primary immunization with bacteriophage $\phi \mathrm{X} 174$. The physiologic lymphccytosis found in the control animals was absent in the experimental group. All lymphoid organs examined in the marasmic pigs displayed marked atrophy as compared to the control animals. No tissues were identified grossly as thymus in the neck or anterior mediastinum of the experimental animals. The germinal centers of the spleen and lymph nodes were poorly formed in the experimental animals. Delayed hypersensitivity to 2,4-dinitrofluorobenzene was demonstrated in only one of the five experimental animals while all four control animals demonstrated delayed hypersensitivity when tested at the same age. Four experimental pigs and three control pigs were immunized with BCG vaccine at 10 months of age. The mean diameter of tuberculin reaction of the experimental group was $6.5 \mathrm{~mm}$; that of the controls was $27 \mathrm{~mm}$ when tested 4 weeks later. Both full thickness skin grafts and split thickness grafts underwent a delayed rejection in the experimental group. Lymphocyte transformation with phytohemagglutinin was studied at 6,9, and 14 months of age in both control and experimental animals with similar results in both groups (Table VIII). Leukocytes from three experimental pigs had no increase in uptake of thymidine when tested in mixed leukocyte culture. Leukocytes from five experimental animals and three control pigs had normal leukocyte bactericidal activity against Staphylococcus aureus and Serratia marcescens. These studies provide presumptive evidence that marasmic pigs have defects in both humoral and cellular immunity. The deficiency in cellular immunity seemed greater and was manifest by thymic involution, lymphopenia, a decreased capacity to express delayed hypersensitivity, delayed homograft rejection, and absence of reactivity in the mixed leukocyte culture.
\end{abstract}




\section{Speculation}

Clinical experience and recent experimental studies indicate that malnutrition decreases resistance to infection. The results presented show that cell-mediated immunity is impaired in malnutrition. Much of the immunodeficiency in malnutrition may be mediated by hyperadrenocorticism.

\section{Introduction}

"Protein-calorie malnutrition coupled with infection is the greatest killer of infants and young children and the major cause of retarded child growth and development in today's world," stated the Committee on International Child Health in 1969 [11]. Infantile marasmus is one of the most common severe nutritional disorders affecting children of developing countries. Marasmus is the result of extreme and prolonged dietary restriction of proteins, calories, and other essential nutrients in early life. Marasmus is to be differentiated from kwashiorkor, which is the result of dietary protein deficits that are greater than dietary deficits in calories. Patients with kwashiorkor have edema and hypoproteinemia. In contrast, marasmic children have more nearly normal protein concentrations and no edema.

Clinical experience has indicated that malnourished children resist infections poorly, though the nature of the host deficiency is somewhat uncertain, no doubt because of the difficulty in conducting well controlled studies in humans $[16,19,23,31]$. Children with protein-calorie malnutrition were reported to have atrophy of lymphoid tissue and a depression of cell-mediated immunity [38]. The studies reported here were designed to investigate the immunologic responses in an experimental model, the marasmic piglet.

\section{Materials and Methods}

Animals. Two litters of minature piglets of the Pitman Moore strain [46] were used. The average weight at birth was $600 \mathrm{~g}$. After weaning at 15 days, they were fed a commercial piglet diet [47]. The young animals reached an average weight of $4 \mathrm{~kg}$ at 35 days of age. The initial litter of nine piglets was divided into two groups with four of the animals serving as controls and five subjected to the experimental dietary restriction. Three additional piglets from a second litter were used as experimental animals, and one of the piglets from this litter served as a control animal. The animals were housed in individual cages. The diet of the exper- imental piglets was adjusted to prevent further significant weight gain after the age of 35 days by restricting their dietary intake to $30 \mathrm{~g}$ of commercial pig diet offered three times daily. This limited dietary intake was continued throughout the entire study period. Water was supplied ad libitum. All animals were given $150 \mathrm{mg}$ of iron by intramuscular injection of iron dextran on the 3rd day of life. All experimental procedures were performed in the temperature-controlled rooms in which the animals were housed.

Weights of four control and five experimental animals are depicted in Figure 1. The experimental animals displayed a well developed characteristic picture of severe undernutrition after 3 months of dietary restriction. There was absence of subcutaneous fat, marked muscle atrophy, and an increased amount of coarse body hair. The striking similarities of those animals to the clinical picture of infantile marasmus have been described in previous studies [30,40].

Serum proteins. Serum protein concentrations and serum protein electrophoresis were performed by methods previously described $[24,28]$. Serum concen-

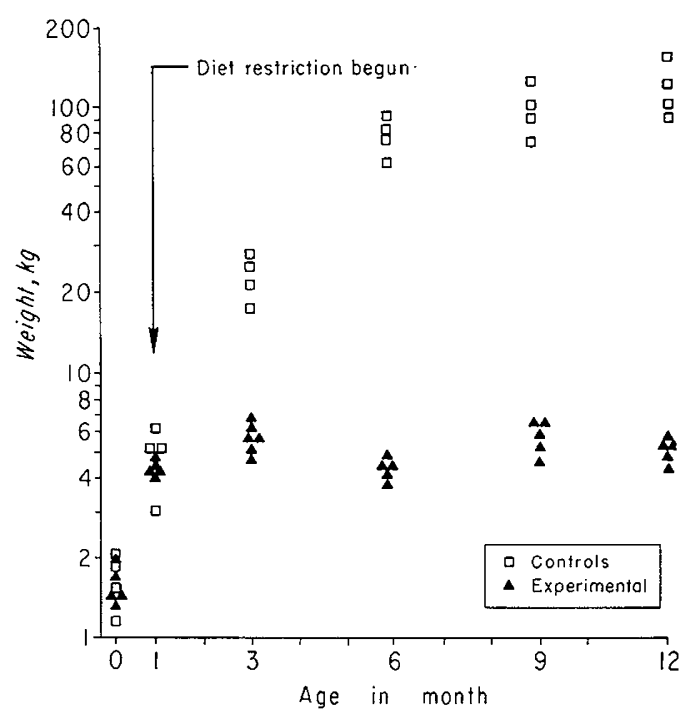

Fig. 1. Weight of control and experimental pigs during the first 12 months of life. Diet restriction of the experimental animals was begun at 35 days of age. 
trations of $\operatorname{IgG}$ and $\operatorname{IgM}$ were measured by single radial immunodiffusion method [29]. Antiserum to porcine IgM [48] and antiserum to porcine $\operatorname{IgG}$ [49] were obtained commercially. Immunologically pure porcine $\operatorname{lgG}[50]$ was used as the standard for $\operatorname{IgG}$ measurements. Purified porcine IgM was not available. The results of IgM determinations were expressed as percentages of a normal adult pig's serum [51].

Antigens and serum antibody determinations. Naturally occurring antibodies to human type A erythrocytes were determined by conventional hemagglutination technique. One milliliter of aluminum hydroxide-absorbed tetanus toxoid [52] was injected intramuscularly at the age of 50 days. Secondary immunization was carried out by giving a similar dose 6 months later. Antibody titers were determined by hemagglutination [39]. A saline suspension of $10^{8}$ sheep erythrocytes (SRBC) per kg body weight in complete Freund's adjuvants [53] was given intramuscularly at the age of 1 year. Anti-SRBC antibody titers were determined by conventional hemagglutination.

The animals were immunized to bacteriophage $\phi \mathrm{X}$ 174 by intravenous injection of $1.5 \times 10^{9}$ plaque-forming units (PFU) of phage per $\mathrm{kg}$ body weight. Three experimental piglets and three controls were immunized at the age of 80 days. A second group was primarily injected at 225 days of age. Secondary immunizations to phage $\phi \mathrm{X} 174$ were carried out 5 weeks later. Antibody activity was measured by phage neutralization and expressed as $\mathrm{K}$-values or rates of phage inactivation [41]. Antibodies to bacteriophage $\phi \mathrm{X} 174$ were further characterized by reduction with 2-mercaptoethanol (2-ME) [18]. After the pigs were immunized with SRBC, selected serum samples were subjected to gel filtration on Sephadex G-200 [54] on 2.5- $\times 100-\mathrm{cm}$ columns using Tris buffer, $\mathrm{pH}$ 7.4. Eluates were collected in 6-ml fractions. The protein concentrations were determined by optical density measurement at $280 \mu$.

Lymphocyte counts. The number of lymphocytes in the peripheral blood was calculated from differential counts of coverslip smears, and total leukocyte counts were performed using a hemocytometer. In one experimental and in one control animal the cisterna chyli were cannulated and lymphocyte counts were determined on the lymph obtained.

Sensitization with dinitrofluorobenzene. 2,4-Dinitrofluorobenzene (DNFB) [55] was diluted 1:10 in $90 \%$ acetone and $10 \%$ olive oil. The animals were sensitized by placing $1-\mathrm{cm}$ squares of filter paper saturated with DNFB on the shaved skin of their backs. Delayed hypersensitivity responses were elicited through intradermal injections of $0.1 \mathrm{ml}$ of $1: 1000$ dilution of DNFB in the medial aspects of the legs.

Sensitization with BCG. BCG [56] was injected subcutaneously with complete Freund's adjuvant. Four weeks after the initial injection, intradermal injections of $0.1 \mathrm{ml}$ mammalian tuberculin [57] were administered. Reactions to the tuberculin were measured $48 \mathrm{hr}$ later.

Histopathology of peripheral lymph nodes, spleen, and thymus. Spleen and lymph nodes were obtained and thymuses were sought at postmortem examinations of three control and four experimental pigs. A peripheral lymph node was obtained from all other animals. The specimens were prepared for histologic examination.

Skin homograft. Two techniques of skin grafting were used. In the first, skin was taken from an unrelated donor pig and three full thickness homografts measuring $2 \mathrm{~cm}$ in diameter were placed on prepared beds in the backs of the experimental and control pigs. In addition, an autograft was placed on each animal. No sutures were taken. In the second technique, skin was again taken from an unrelated donor using a dermatone set to cut pieces of skin $10 \times 5 \mathrm{~cm}$ and 0.02 $\mathrm{mm}$ in thickness. The skin was then cut into small pieces $(1 \times 1 \mathrm{~cm})$. As many as 10 homografts were placed on a prepared bed of a single animal. Five autografts served as controls. The animals were anesthetized with intravenous phenobarbital. Second set grafts were not done.

Lymphocyte transformation with phytohemagglutinin $(P H A)$. Blood was drawn in plastic syringes containing 100 units heparin per ml blood. Mononuclear cells were counted using a counting chamber. Aliquots of whole blood containing $10^{6}$ mononuclear cells were placed in culture tubes containing $3 \mathrm{ml} \mathrm{Ea}$ gle's TC medium [58] supplemented with $20 \%$ autologous pig serum, 500 units penicillin per $\mathrm{ml}$, and $0.1 \mathrm{ml}$ 1:10 dilution of PHA-M [59]. Total volumes were made up to $4 \mathrm{ml}$ with TC medium. Control tubes were set up without PHA. These cultures were incubated for $72 \mathrm{hr}$ at $37^{\circ}$. Eight hours before the end of the incubation period $4 \mu \mathrm{Ci}{ }^{3} \mathrm{H}$-thymidine [60] were added to each tube. The cells were harvested by centrifuging the cultures at $1000 \mathrm{rpm}$ for $10 \mathrm{~min}$. The supernatant was then discarded, and the sediment was washed twice with $5 \mathrm{ml}$ cold $0.2 \% \mathrm{NaCl}$. The cultures were centrifuged again, and, after the supernatant was discarded, $2 \mathrm{ml}$ cold $5 \%$ trichloroacetic acid (TCA) were added to each tube. The tubes were then left over- 
Table 1 . Total serum proteins and serum albumin concentrations of experimental and control pigs at 3, 6, and 12 months of $\operatorname{age}^{1}$

\begin{tabular}{cccc}
\hline Anima group & $\begin{array}{c}3 \mathrm{mos} \\
(55 \text { days })^{2}\end{array}$ & $\begin{array}{c}6 \mathrm{mos} \\
(146 \mathrm{days})^{2}\end{array}$ & $\begin{array}{c}12 \mathrm{mos} \\
(330 \mathrm{days})^{2}\end{array}$ \\
\hline \multicolumn{4}{c}{ Total protein, $\mathrm{g} / 100 \mathrm{ml}$} \\
$\begin{array}{c}\text { Experimental } \\
(N=7)\end{array}$ & $6.3 \pm 0.31^{2}$ & $6.74 \pm 0.23$ & $6.10 \pm 0.38$ \\
$\begin{array}{c}\text { Control } \\
(N=5)\end{array}$ & $6.4 \pm 0.13$ & $7.90 \pm 0.47$ & $7.36 \pm 0.50$ \\
$\quad$ Albumin, $\mathrm{g} / 100 \mathrm{ml}$ \\
$\begin{array}{c}\text { Experimental } \\
(N=7)\end{array}$ & $3.0 \pm 0.34$ & $3.01 \pm 0.36$ & $3.02 \pm 0.21$ \\
$\begin{array}{l}\text { Control } \\
(N=5)\end{array}$ & $3.14 \pm 0.25$ & $4.27 \pm 0.73$ & $3.86 \pm 0.27$ \\
\hline
\end{tabular}

${ }^{1}$ Values are expressed as means $\pm \mathrm{sD}$.

2 Days on diet for experimental group.

Table II. IgG concentrations, in $\mathrm{mg} / 100 \mathrm{ml}$, of experimenta and control pigs ${ }^{1}$

\begin{tabular}{crr}
\hline Age & \multicolumn{1}{c}{ Experimental } & \multicolumn{1}{c}{ Control } \\
\hline 2 days & $2281 \pm 788$ & $2000 \pm 993$ \\
1 month & $542 \pm 127$ & $475 \pm 194$ \\
3 months & $1076 \pm 165$ & $1012 \pm 125$ \\
6 months & $1060 \pm 155$ & $1474 \pm 223$ \\
12 months & $1257 \pm 91$ & $1089 \pm 133$ \\
\hline
\end{tabular}

${ }^{1}$ Values are expressed as means \pm SD for 7 experimental and 5 control animals.

night at $4^{\circ}$ and then centrifuged at $2000 \mathrm{rpm}$. The supernatant was discarded. DNA was extracted with $0.5 \mathrm{ml} 5 \%$ TCA and heated at $95^{\circ}$ twice for $10 \mathrm{~min}$. Tubes were centrifuged once again, and $0.3 \mathrm{ml}$ supernatant was placed in the vials containing $9 \mathrm{ml}$ scintillation counting fluid made up of $4 \mathrm{~g}$ PPO [61] per liter toluene and $0.7 \mathrm{ml}$ solubilizer [62]. Specimens were counted in a Beckman scintillation counter. Counts were expressed as number per $10^{5}$ cells. All culture tubes were set up in triplicate.

Mixed leukocyte culture. One-way mixed leukocyte cultures were carried out as described [1]. Leukocytes of a nonrelated donor were used to stimulate the responding cells. TCI 99 was buffered to a $\mathrm{pH}$ of 7.4 with "Hepes" ( $N$-2-hydroxyethylpiperazine- $N$ '-2-ethanesulfuric acid) [63]. Cultures were incubated for $72 \mathrm{hr}$ and then pulsed with ${ }^{3} \mathrm{H}$-thymidine for $18 \mathrm{hr}$. The preparation of the material for counting was carried out essentially as described above.

Passive transfer of delayed hypersensitivity. A leukocyte suspension of cells from a highly sensitive DNFBpositive control was prepared as described above. Aliquots containing $5 \times 10^{6}$ mononuclear cells were in- jected subcutaneously into four experimental animals which had been shown to have lost DNFB hypersensitivity.

Leukocyte bactericidal activity. The bactericidal activity of leukocytes in peripheral blood was assayed as previously described [26].

\section{Results}

Serum proteins. Serum albumin concentrations of the experimental group were lower than controls at 6 and 12 months (Table I). IgG and IgM concentrations of both experimental and control pigs were similar (Tables II and III).

Serum antibody. Antibody against erythrocyte A-antigen first appeared in control animals at the age of 2 months and rose progressively in titer during the next 5 months. Anti-A titers of experimental pigs were consistently lower (Table IV).

Antibody responses after immunization to tetanus toxoid, SRBC, and bacteriophage $\phi \mathrm{X} 174$ were remarkably similar in both groups (Tables V and VI). The bacteriophage $\phi \mathrm{X} 174$ was cleared from the circulation by 1 week after immunization. All of the animals showed an increase in antibody titer after secondary immunization.

Table III. IgM concentrations of experimental and control pigs ${ }^{1}$

\begin{tabular}{ccc}
\hline Age & $\begin{array}{c}\text { Experimental }(N=7), \\
\% \text { adult serum }\end{array}$ & $\begin{array}{c}\text { Control }(N=5), \\
\% \text { adult serum }\end{array}$ \\
\hline 1 day & $115 \pm 46$ & $115 \pm 46$ \\
10 days & $<10$ & $<10$ \\
45 days & $51 \pm 7$ & $52 \pm 15$ \\
3 months & $103 \pm 22$ & $102 \pm 14$ \\
6 months & $101 \pm 16$ & $102 \pm 17$ \\
\hline
\end{tabular}

${ }^{1}$ Values are expressed as means $\pm \mathrm{sD}$.

Table IV. Reciprocals of natural anti-A hemagglutination titers of experimental and control pigs

\begin{tabular}{lrrrr}
\hline & \multicolumn{4}{c}{ Age, mos } \\
\cline { 2 - 5 } Animal & \multicolumn{1}{c}{3} & \multicolumn{1}{c}{3} & \multicolumn{1}{c}{5} \\
\hline C1 & 4 & 32 & 64 & 128 \\
C2 & 16 & 32 & 32 & 64 \\
C3 & 4 & 8 & 16 & 32 \\
C4 & 8 & 32 & 64 & 128 \\
E1 & 0 & 2 & 4 & 8 \\
E2 & 0 & 4 & 4 & 8 \\
E3 & 2 & 4 & 16 & 32 \\
E4 & 0 & 8 & 8 & 8 \\
E5 & 8 & 8 & 8 & 8 \\
\hline
\end{tabular}

${ }^{1} \mathrm{Cl}$ : Control animal 1.

${ }^{2}$ E1 : Experimental animal 1. 
Immunoglobulin class of antibodies. As shown in Table VI, most of the antibody obtained 1 week after immunization was sensitive to treatment with $2-\mathrm{ME}$. Four weeks after primary immunization most of the antibody from experimental animals was sensitive to 2-ME whereas antibody from controls was resistant. The experimental animals thus had a delay in appearance of IgG antibody after primary immunization. Both experimental and control groups made IgG antibody after secondary immunization.

Gel filtration of serum samples from two control

Table $V$. Reciprocals of antibody titers to tetanus toxoid and sheep red blood cells after primary and secondary immunizations

\begin{tabular}{lrrrrr}
\hline & \multicolumn{2}{c}{ Tetanus toxoid } & & \multicolumn{2}{c}{ Sheep erythrocytes } \\
\cline { 2 - 3 } \cline { 5 - 6 } Animal & $\begin{array}{c}\text { 4 weeks } \\
\text { after } \\
\text { primary }\end{array}$ & $\begin{array}{c}4 \text { weeks } \\
\text { after } \\
\text { secondary }\end{array}$ & & $\begin{array}{c}\text { 10 days } \\
\text { after } \\
\text { primary }\end{array}$ & $\begin{array}{c}\text { 10 days } \\
\text { after } \\
\text { secondary }\end{array}$ \\
\hline C1 ${ }^{1}$ & 320 & 1280 & & 512 & 2048 \\
C2 & 1280 & 20480 & & 128 & 1024 \\
C3 & 80 & 320 & & 128 & 1024 \\
C4 & 1280 & & & 64 & 256 \\
C5 & 320 & 5120 & & 64 & \\
E1 & 80 & 1280 & & 1024 & 2048 \\
E2 & 80 & 5120 & & 512 & 1024 \\
E3 & 80 & 5120 & & 256 & 1024 \\
E4 & 1280 & 5120 & & 128 & 512 \\
E5 & 5210 & & 128 & 512 \\
E6 & 320 & & 64 & 256 \\
\hline
\end{tabular}

$1 \mathrm{Cl}$ : Control animal 1.

${ }^{2} \mathrm{El}$ : Experimental animal 1.

Table VI. Antibody response to bacteriophage $\phi \mathrm{X} 174$

\begin{tabular}{|c|c|c|c|c|c|c|c|}
\hline \multirow{3}{*}{ Animal } & \multirow{3}{*}{$\begin{array}{c}\begin{array}{c}\text { Days } \\
\text { on } \\
\text { diet }\end{array} \\
50\end{array}$} & \multicolumn{4}{|c|}{$\begin{array}{c}\text { Primary } \\
\text { immunization }\end{array}$} & \multicolumn{2}{|c|}{$\begin{array}{c}\text { Secondary } \\
\text { immunization }\end{array}$} \\
\hline & & \multicolumn{2}{|c|}{1 week } & \multicolumn{2}{|c|}{4 weeks } & \multirow{2}{*}{$\frac{1 \text { week }}{26.2}$} & \multirow{2}{*}{$\frac{4 \text { weeks }}{16.3}$} \\
\hline & & $7.9^{3}$ & $(<0.1)^{4}$ & 1.4 & $(1.3)$ & & \\
\hline $\mathrm{C} 2$ & 50 & 4.8 & $(<0.1)$ & 0.58 & $(0.52)$ & $\mathrm{ND}^{5}$ & ND \\
\hline C3 & 200 & 0.47 & $(<0.1)$ & 13.3 & (13) & ND & ND \\
\hline $\mathrm{C} 4$ & 200 & 1.2 & $(0.12)$ & 1.26 & $(1.12)$ & 22.0 & 11.6 \\
\hline C5 & 50 & 2.9 & $(0.9)$ & 0.15 & $(0.09)$ & $\mathrm{ND}$ & $\mathrm{ND}$ \\
\hline $\mathrm{El}^{6}{ }^{6}$ & 200 & 7.1 & $(0.21)$ & 16.1 & $(3.0)$ & ND & ND \\
\hline $\mathrm{E} 2$ & 50 & 1.23 & & 1.1 & $(0.2)$ & 77.5 & 21.8 \\
\hline E3 & 200 & 0.3 & $(0.13)$ & 1.3 & $(0.34)$ & 13.8 & 16.0 \\
\hline $\mathrm{E} 4$ & 50 & 24.8 & $(0.1)$ & 5.8 & $(0.82)$ & 15.2 & ND \\
\hline E5 & 200 & 0.17 & & 6.1 & $(0.78)$ & 26.2 & ND \\
\hline E6 & 50 & 7.3 & $(0.24)$ & 1.3 & $(0.56)$ & 8.8 & 11.5 \\
\hline
\end{tabular}

${ }^{1}$ Essentially no IgM antibody was detected after secondary immunization.

${ }^{2} \mathrm{Cl}$ : Control animal 1.

${ }^{3}$ Neutralizing antibody expressed as K-values (see text).

${ }^{4}$ Neutralizing antibody after treatment with $2-\mathrm{ME}$.

${ }^{5} \mathrm{ND}$ : not done.

${ }^{6}$ E1: Experimental animal 1.

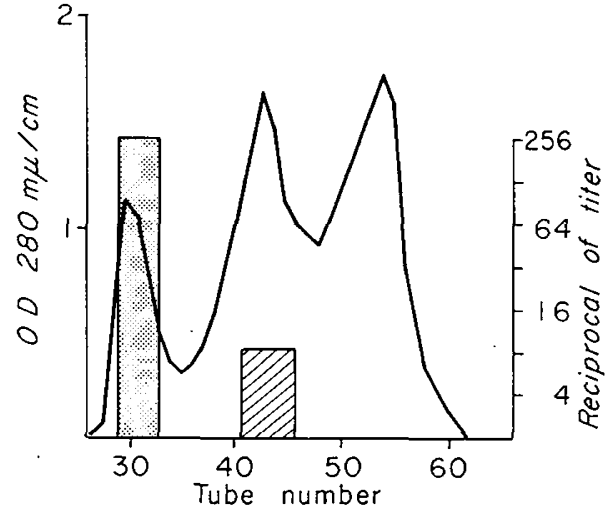

Fig. 2. Chromatography on Sephadex G-200 of a serum pool from control animals 10 days after primary immunization with SRBC. Tubes from the first and second protein peaks were pooled separately and tested for hemagglutinating activity. The bulk of the antibody detected by this method eluted in the first protein peak. Identical results were obtained in a similar study on a serum pool from experimental animals.

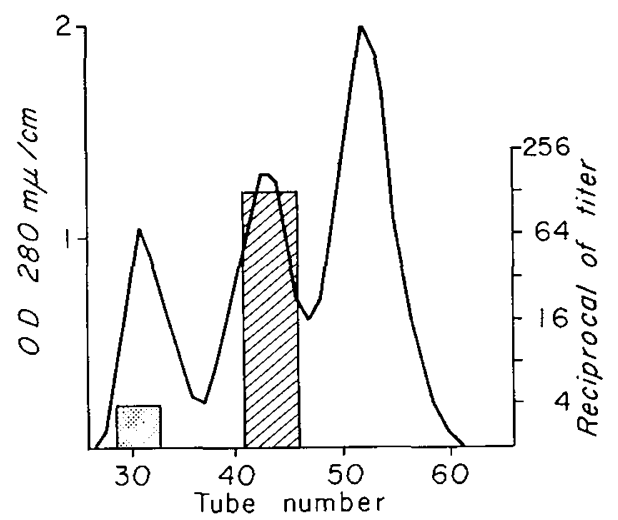

Fig. 3. Chromatography on Sephadex G-200 of a serum pool from control animals 25 days after primary immunization with SRBC. Tubes from the first and second protein pcaks were pooled separately and tested for hemagglutinating activity. The bulk of the antibody detected by this method eluted in the second protein peak.

pigs taken 10 days after primary immunization with SRBC demonstrated that most of the antibody eluted in the first peak and was presumably IgM (Fig. 2). Serum samples obtained 25 days after primary immunization of control pigs with SRBC contained predominantly antibody eluting in the second peak, presumably IgG (Fig. 3). A pool of serum samples obtained from three experimental pigs taken 10 days after primary immunization with SRBC demonstrated a similar pattern to that shown in Figure 2. Most of the antibody eluted in the first protein peak. Serum samples obtained from the experimental animals 25 days after primary immunization demonstrated that most of 


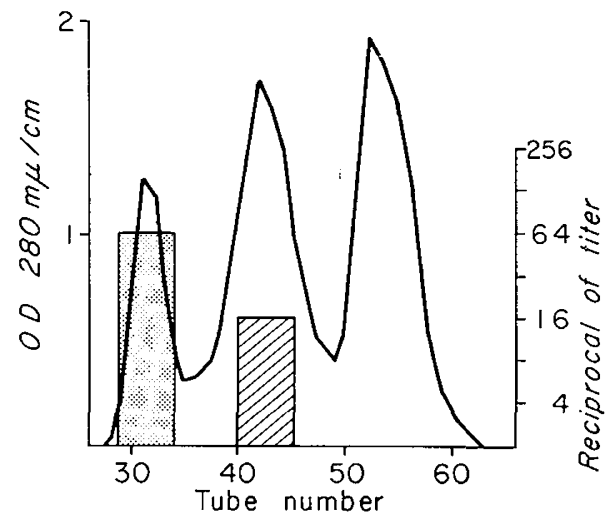

Fig. f. Chromatography on Sephadex G-200 of a serum pool from experimental animals 25 days after primary immunization. In contrast with the findings in the control animals (Fig. 3), most of the antibody activity eluted in the first protein peak.

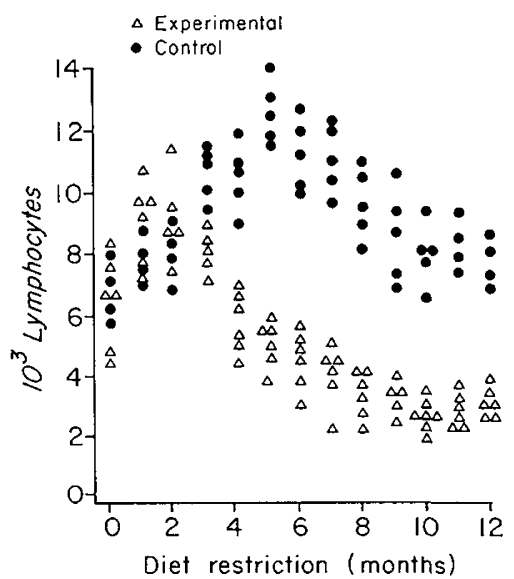

Fig. 5. Absolute lymphocyte counts of controls and experimental animals.

the antibody was still in the first peak and was presumably IgM (Fig. 4). These results are consistent with those obtained with 2-ME.

Lymphocyte counts. The lymphocyte counts from experimental and control pigs during the first 12 months of diet restriction are shown in Figure 5. The physiologic lymphocytosis found in the control animals was absent in the experimental group. Lymph was aspirated from the cisterna chyli in one experimental pig and one control pig at the age of 6 months. The experimental pig had $0.14 \times 10^{6}$ cells per $\mathrm{mm}^{3}$, and the control pig had $7.1 \times 10^{6}$ cells per $\mathrm{mm}^{3}$ of lymph.

Morphology of lymphoid structures. All lymphoid organs examined in the marasmic pigs displayed marked atrophy as compared to the control animals. No tissues were identified grossly as thymus in the neck or anterior mediastinum of the experimental animals. Histologic examination of the mediastinal connective tissue from experimental animals showed predominantly loose collagenous connective tissue. No adipose cells were seen. Focal aggregates of small spindle-shaped cells were found in the connective tissue elements. Some of these aggregates contained Hassall's corpuscles with keratinized cells. The spleen and lymph nodes of the experimental animals were smaller and hypocellular as compared to the controls. The germinal centers of the spleen and lymph nodes were poorly formed in the experimental animals. The splenic periarteriolar lymphoid tissue was more nearly normal in the experimental animals. Eosinophils were rarely seen.

Delayed hypersensitivity to $D N F B$ and $B C G$. Five experimental pigs and four controls were sensitized with 2,4-dinitrofluorobenzene at 25 days of age. Delayed hypersensitivity was demonstrated in all experimental and control pigs 15 days later. Five experimental animals were retested after 46 days of diet restriction. Delayed hypersensitivity was demonstrated in only one of the five experimental animals while all four control animals demonstrated delayed hypersensitivity when tested at the same age. The animals were again tested at 126 days of age. None of the experimental animals expressed delayed hypersensitivity while three of the control animals reacted.

An attempt was made to transfer passively delayed hypersensitivity to DNFB in the four experimental animals at 128 days of age. Twenty-four hours after injection of a leukocyte suspension from a sensitized animal, four of the four injected experimental animals expressed delayed hypersensitivity to DNFB.

Four experimental pigs and three control pigs were immunized with $B C G$ vaccine at 10 months of age. All were injected with tuberculin 4 weeks later. The mean diameter of induration of the experimental group was $6.5 \mathrm{~mm}$; that of the controls was $27 \mathrm{~mm}$. The main thickness of induration was $2 \mathrm{~mm}$ in the experimental group and $6 \mathrm{~mm}$ in the control group.

Skin homografts. Results of skin homograft studies in experimental control animals are shown in Table VII. Both full thickness grafts and split thickness grafts underwent a delayed rejection in the experimental group. The full thickness grafts were applied at 10 months of age and the split thickness grafts at 12 months of age.

Lymphocyte transformation. Lymphocyte transformation with phytohemagglutinin was studied at 6,9 , and 14 months of age in both control and experimen- 
Table VII. First set skin homograft rejection in experimental and control pigs

\begin{tabular}{|c|c|c|c|c|}
\hline \multirow{2}{*}{ Group } & \multirow{2}{*}{$\begin{array}{c}\text { Method } \\
\text { (No. of animals) }\end{array}$} & \multirow{2}{*}{$\begin{array}{l}\text { No. of } \\
\text { skin } \\
\text { grafts }\end{array}$} & \multicolumn{2}{|c|}{$\begin{array}{c}\text { Graft rejection, } \\
\text { days }\end{array}$} \\
\hline & & & Median & Range \\
\hline \multirow[t]{2}{*}{ Control } & $\begin{array}{l}\text { Full thickness } \\
\quad(N=3)\end{array}$ & 9 & 7 & $5-9$ \\
\hline & $\begin{array}{l}\text { Split thickness } \\
\quad(N=1)\end{array}$ & 10 & 8 & $7-10$ \\
\hline \multirow[t]{2}{*}{ Experimental } & $\begin{array}{l}\text { Full thickness } \\
\quad(N=6)\end{array}$ & 18 & 13 & $7-19$ \\
\hline & $\begin{array}{l}\text { Split thickness } \\
\quad(N=2)\end{array}$ & 20 & 15 & $12-18$ \\
\hline
\end{tabular}

Table VIII. Tritiated thymidine incorporation of lymphocytes stimulated with phytohemagglutinin in 9-month-old experimental and control pigs ${ }^{1}$

\begin{tabular}{cc} 
Animal & Counts/min/10 mononuclear cells ${ }^{2}$ \\
\hline C1 $^{3}$ & $46,877 \pm 11,590$ \\
C2 & $50,674 \pm 16,800$ \\
C3 & $61,371 \pm 16,700$ \\
E1 & $39,520 \pm 3,514$ \\
E2 & $58,066 \pm 5,049$ \\
E3 & $55,709 \pm 10,271$ \\
E4 & $52,421 \pm 10,298$ \\
E5 & $69,206 \pm 23,900$
\end{tabular}

${ }_{1}$ Control cultures of unstimulated lymphocytes all had less than 2000 counts per minute per $10^{5}$ mononuclear cells.

${ }^{2}$ Each value is a mean \pm SD of 3 replicate tubes.

" $\mathrm{Cl}$ : Control animal 1.

${ }^{4} \mathrm{El}$ : Experimental animal 1.

tal animals with similar results in both groups (Table VIII). Results of mixed leukocyte cultures at 14 months of age are shown in Figure 6. Leukocytes were obtained from three experimental pigs, two control pigs, and one nonrelated donor pig. The results are presented as thymidine incorporation of stimulated and nonstimulated leukocytes in culture. It will be observed that the stimulated donor and control leukocytes incorporated significantly increased amounts of thymidine, whereas leukocytes from three experimental pigs had no increase in uptake of thymidine when mixed with donor leukocytes.

Leukocyte bactericidal activity. Leukocytes from five experimental animals and three control pigs were tested for leukocyte bactericidal activity with Staphylococcus aureus and Serratia marcescens. The tests were performed at 3, 6, and 12 months of age. Leukocytes from both the experimental and control animals killed the bacteria at a rate comparable to that seen in healthy adult humans.

\section{Discussion}

These studies provide presumptive evidence that marasmic pigs have defects in both humoral and cellular immunity. The deficiency in humoral immunity was apparent as a delayed appearance of $\lg G$ antibody after immunization with bacteriophage $\phi \mathrm{X} 174$ and sheep erythrocytes and low titers of natural anti-A antibodies. The low titers of anti-A antibodies may be due in part to the limited antigenic content of the restricted diet. The deficiency in cellular immunity seemed greater and was manifest by thymic involution, lymphopenia, a decreased capacity to express delayed hypersensitivity, delayed homograft rejection, and absence of reactivity in the mixed leukocyte culture.

The findings complement those of clinical studies on infections and malnutrition. Severe malnutrition is largely a problem of infants and preschool children in underdeveloped countries. Infections and malnutrition most often act synergistically in this age group. The metabolic demands of infection often accentuate the manifestations of nutritional deficiency, and common infectious diseases are more severe in malnourished children [37]. The case fatality rate of measles in Guatemalan villages was $11.5 \%$ in infants and $4.5 \%$ in all age groups [17]. The peak mortality rate was in the 2 nd year of life. Whooping cough, mumps, chicken pox, and rubella were also more severe in malnourished children [36].

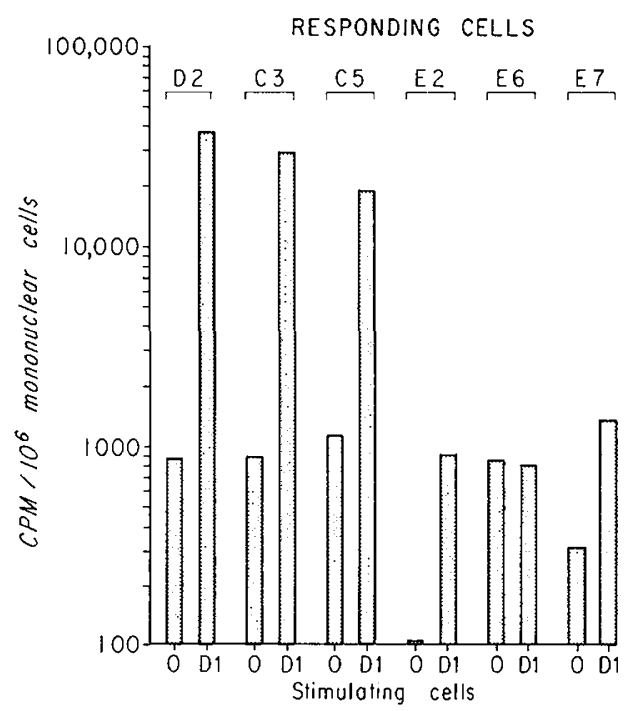

Fig. 6. One-way mixed leukocyte culture of cells from an unrelated donor pig (D2), two control pigs (C3 and C5), and three experimental pigs $(E 2, E 6, E 7)$. Stimulating cells from a second unrelated donor pig $(D I)$ were treated with mytomycin $\mathrm{C}$ to prevent incorporation of ${ }^{3} \mathrm{H}$-thymidine when compared with results in unstimulated cultures. 
There are few reports of clinical studies on humoral immunity in malnutrition. Total serum proteins and serum immunoglobulins were normal in marasmic children [9], except that IgM concentrations were elevated [32]. Antibody responses in marasmic children have apparently not been investigated. In kwashiorkor, both normal and decreased antibody responses were found $[4,6,14,33,34]$.

Cellular immunity seemingly was not investigated systematically in malnourished children until recently. Isolated observations were made of lymphopenia [8], thymic and lymphoid hypoplasia at autopsy [43], and diminution in the tuberculin reaction in tuberculous children [20] and after BCG vaccination [21]. Passive transfer of delayed hypersensitivity to tuberculin was effective in one study [5].

In a study of black African children with proteincalorie malnutrition, Smythe et al. [38] found lymphoid hypoplasia, lymphopenia, decreased capacity to express delayed hypersensitivity, and impaired transformation of lymphocytes with phytohemagglutinin. Our results and those of Smythe et al. complement each other in concluding that protein-calorie malnutrition produces a deficiency of cell-mediated immunity.

Malnutrition has been reported to enhance and also to diminish resistance of experimental animals to infection [37]. As pointed out by Woodruff and Kilbourne, most of these studies were done prior to 1950 , and investigators were necessarily limited in the techniques available for study. In a careful analysis, malnutrition was found to increase the susceptibility of mice to Coxsackie $B$ virus infections. Malnourished mice had an increased tissue concentration of virus, gross cardiac lesions, hepatic lesions, and increased mortality [45].

Woodruff also found that malnourished mice had lymphoid hypoplasia, lymphopenia, decreased early antibody response, and decreased interferon production. Feeding of a normal diet for 40 days restored the normal resistance to viral infections and normal appearance of lymphoid tissue [44].

The findings reported here in marasmic pigs, the experimental studies of Woodruff, and clinical observation all support the concept that malnutrition allows common infections to exhibit greater severity by decreasing host immunologic responses. Both humoral and cellular immunity seem to be affected though the defects in cellular immunity may be more significant. Defects in other mechanisms of host resistance, such as interferon, may also be important.

The immunologic impairment of malnutrition may be mediated, in part, by hyperfunction of the adrenal cortex. Starvation is known to cause adrenal hyperplasia [2]. Plasma cortisol levels were high in marasmic children [25]. Corticosteroids are capable of producing most of the changes of immunologic function seen in marasmus, including lymphopenia, thymic atrophy, lymphoid hypoplasia, impaired antibody response, and defective cellular immunity $[13,42]$.

Cohen and Claman [10] recently presented evidence that the corticosteroid-sensitive phase of the mouse antibody response to sheep red blood cells was the bone marrow-derived precursor of antibody-forming cells. The influence of corticosteroids on immunologic function is complex and requires further investigation.

Adrenal hormones may not mediate all of the effects of malnutrition on immunity. Woodruff [45] found that adrenalectomy of starved animals only partially corrected the abnormality in absolute lymphocyte counts.

The delay in appearance of IgG antibody in marasmic pigs is apparently not caused by a failure in maturation of the pigs, since Kim et al. [27] have demonstrated that the young piglet has the same antibody response as the mature animal.

The present study provides another example of the relative resistance of the IgM-producing cells to insult. $\mathrm{IgG}$ antibody response is also suppressed to a relatively greater extent than IgM antibody response by immunosuppressive drugs [12, 35], antilymphocyte serum [15], and irradiation [22].

The thymic involution and lymphoid hypoplasia in the marasmic pigs were similar to those reported in malnourished animals [2] and man [43]. There was a striking depletion of lymphocytes, lymphoid follicles, and germinal centers in the lymph nodes of the marasmic pigs. Similar changes have been produced by administration of large doses of corticosteroids [3].

Divergent results were obtained in studies on lymphocyte transformations with phytohemagglutinin and in the mixed leukocyte culture. Lymphocytes from marasmic pigs functioned normally in the test with phytohemagglutinin but failed to react in the mixed leukocyte culture. A similar dissociation of lymphocyte transformation with phytohemagglutinin and the mixed leukocyte culture was observed in adult thymectomized rats treated with antilymphocyte serum [7]. This dissociation may be due to a quantitative deficiency in normally functioning thymus-derived lymphocytes. Relatively more normal thymus-derived lymphocytes may be necessary for a normal response in the 
mixed leukocyte culture than in the transformation reaction with phytohemagglutinin.

Malnutrition is one of the most important health problems in the world, and infection constitutes one of the major causes of morbidity and mortality. Much remains to be learned concerning the interactions between nutrition, infections, and host resistance. Before the interaction between infection and malnutrition can be understood, further investigations will be required on immunologic function in malnourished children, immunologic function in malnourished animals, and resistance of malnourished animals to experimental infections.

\section{References and Notes}

1. Amos, D. B., AND BACH, F. H.: Phenotypic expressions of the major histocompatibility locus in man (HL-A): leukocyte antigens and mixed leukocyte culture reactivity. J. Exp. Med., 128: 623 (1968).

2. Andreasen, E.: The thymolymphatic system during inanition and restitution. Acta Pathol. Microbiol. Scand. Suppl. XLIX (1943).

3. Baker, B. L., Ingle, D. J., ANd Choh Hao LI: The histology of the lymphoid organs of rats treated with adrenocorticotropin. Amer. J. Anat., $88: 313$ (1951).

4. BRown, R. E., AND Katz, M.: Failure of antibody production to yellow fever vaccine in children with kwashiorkor. Trop. Geogr. Med., 18: 125 (1966).

5. Brown, R. E., ANd Katz, M.: Passive transfer of delayed hypersensitivity reaction to tuberculin in children with protein calorie malnutrition. J. Pediat., 70: 126 (1967).

6. Budiánsky, E., ANd DA Silva, N. N.: Formaćāo de anticorpos na distrofia pluricarencial hidropigencia. Hospital (Rio de Janeiro), 52: 251 (1957).

7. Carlson, L. S., and Schwarz, M. R.: Thymectomy, antilymphocyte serum (ALS), and the mixed lymphocyte reaction (MLR). In: O. R. McIntyre: Proceedings of the 4th Leucocyte Culture Conference. (Dartmouth, Hanover, N. H., 1969).

8. Castellanos, H., and Arroyave, G.: Role of the adrenal cortical system in the response of children to severe protein malnutrition. Amer. J. Clin. Nutr., 9: 186 (1961).

9. Chatterjee, S., Bhatracharyya, A. K., and Mandal, J. N.: Serum proteins in kwashiorkor and marasmus: 1 . Unselected series before treatment. Bull. Calcutta Sch. Trop. Med., 16: 35 (1968).

10. Cohen, J. J., and Glaman, H. N.: Thymus-marrow immunocompetence. V. Hydrocortisone-resistant cells and processes in the hemolytic antibody response of mice. J. Exp. Med., 133: 1026 (197I).

11. Committee on International Child Health: Malnutrition in the World's Children. Pediatrics, 43: I31 (1969).

12. Dukor, P., And Dietrich, F. M.: The immune response to heterologous red cells in mice. V. The effect of cyclophosphamide and cortisone on antigenic competition. J. Immunol., 105: 118 (1970).

13. Durkin, H. G., and Thorbeke, G. J.: Relationship of germinal centers in lymphoid tissue to immunologic memory. $\mathrm{V}$.
The effect of prednisolone administered after the peak of the primary response. J. Immunol., 106: 1079 (1971).

14. Fernandez, N. A.: Serum antibody response of malnourished children as compared with well nourished children. Bol. Asoc. Med. P. R., 52: 222 (1960).

15. Field, E. J., Hughes, D., and Caspary, E. A.: Mode of action of antilymphocyte serum. Lancet, $i i$ : 964 (1969).

16. Gordon, J. F., Guzman, M. A., Ascoli, W., and Scrimshaw, N. S.: Acute diarrhoeal disease in less developed countries. 2. Patterns of epidemiological behaviour in rural Guatemalan villages. Bull. World Health Organ., 31: 9 (1964).

17. Gordon, J. E., Jansen, A. A. J., And Ascoli, W.: Measles in rural Guatemala. J. Pediat., 66: 779 (1965).

18. Grubb, R., And Swahn, B.: Destruction of some agglutinins but not of others by two sulfhydryl compounds. Acta Pathol. Microbiol. Scand., 43: 305 (1958).

19. Hald, S. A.: Nutrition and infection. East Afr. Med. J., 16:58 (I969).

20. Harland, P. S.: Tuberculin reactions in malnourished children. Lancet, ii: 791 (I965).

21. Harland, P. S., and Brown, R. E.: Tuberculin sensitivity testing following BCG vaccination in undernourished children. East Afr. Med. J., 42: 233 (1965).

22. Hasek, M., ANd Lengerova, A.: Immunology. In: Mechanisms of Radiobiology, Vol. II, p. 207 (Academic Press, New York, $1960)$.

23. HENDRICKSE, R. G.: Interactions of nutrition and infection: experience in Nigeria. In: G. E. W. Wolstenholme and M. O'Connor: Nutrition and Infection, p. 98. (Ciba Foundation Group No. 31, Churchill, London, 1967).

24. Hufrga, J. De la, Smetters, G. W., and Sherrick, J. C.: Chlorometric determination of serum protein: the Biuret reaction. In: F. W. Sunderman and F. W. Sunderman: Serum Proteins and the Dysproteinemias, p. 54. (Pitman Medical, L.ondon, 1964).

25. Kamala, S. J. R., SRikantia, S. G., and Gopalan, C.: Plasma cortisol levels in protein-calorie malnutrition. Arch. Dis. Childhood, 43: 365 (1968).

26. Kaplan, E. L., Laxdal, T., And Quie, P. G.: Studies on polymorphonuclear leukocytes from patients with chronic granulomatous disease of childhood: bactericidal capacity for streptococci. Pediatrics, 41:591 (1968).

27. Kin, Y. B., Bradley, S. G., and Watson, D. W.: Ontogeny of the inmune response. I. Development of immunoglobulins in germ-free and conventional colostrum-deprived piglets. J. Immunol., $97: 52$ (1966).

28. КонN, J.: Cellulose acetate membrane (CAM) clectrophoresis. In: C. A. Williams and M. W. Chase: Methods in Immunology and Immunochemistry, Vol. II, p. 20. (Academic Press, New York, 1968).

29. López, V., ANd Golder, S.: A new immunodiffusion method for quantitative determination of proteins in biological fluids based on a separated application of antibody and antigen to small agar discs. Clin. Chim. Acta, 21: 517 (1968).

30. McC.ance, L. A., And Mount, L. E.: Severe undernutrition in growing and adult animals. 5. Metabolic rate and body temperature in the pig. Brit. J. Nutr., 14:509 (1960).

31. Morley, D.: The public health problems created by measles in the developing countries. Arch. Gesamte Virusforsch., 16: 19 (1965).

32. NajJar, S. S., Stephan, M., and Asfour, R. Y.: Serum levels 
of immunoglobulins in marasmic infants. Arch. Dis. Childhood, 44: 120 (1969).

33. Pretorius, P. J., and De Villiers, L. S.: Antibody response in children with protein malnutrition. Amer. J. Clin. Nutr., 10: 379 (1962).

34. Reddy, V., and Srikantia, S. G.: Antibody response in kwashiorkor. Indian J. Med. Res., 52: 1154 (1964).

35. Sahiar, K., And Schwartz, R. S.: The immunoglobulin sequence. I. Arrest by 6 -mercaptopurine and restitution by antibody, antigen or spleenotomy. J. Immunol., 95: 345 (1965).

36. Salomon, J. B., Mata, L. J., And Gordon, J. E.: Malnutrition and the common communicable diseases of childhood in Guatemala. Amer. J. Public Health, 58: 505 (1968).

37. Scrimshaw, N. S., TAylor, C. E., and Gordon, J. E.: Interactions of nutrition and infection. World Health Organ. Monogr. Ser. 57 (1968).

38. Smythe, P. M., Brereton-Stiles, G. G., Grace, H. J., Mafoyane, A., Schonland, M., Coovadia, H. M., Loening, W. E. K., Parent, M. A., and Vos, G. H.: Thymolymphatic deficiency and depression of cell-mediated immunity in protein-calorie maInutrition. Lancet, $i i$ : 7731 (1971).

39. Sravitsky, A. B.: Micromethods for the study of proteins and antibodies. I. Procedure and general applications of hemagglutination and hemagglutination-inhibition reactions with tannic acid and protein-treated red blood cells. J. Immunol., 72: 360 (1954).

40. Steckel, A., and SMrth, N. J.: Hematologic studies of severe undernutrition of infancy. I. The anemia of prolonged caloric deprivation in the pig. Pediat. Res., 3: 338 (1969).

41. Uhr, J. W., Finkelstern, M. S., and Baumann, J. B.: Antibody formation. III. The primary and secondary antibody response to bacteriophage $\phi \mathrm{X} 174$ in guinea pigs. J. Exp. Med., 115: 655 (1962).

42. Ward, P., AND Johnson, A. G.: Studies on the adjuvant action of bacterial endotoxins on antibody formation. II. Antibody formation in cortisone-treated rabbits. J. Immunol., 82 : 427 (1958).

43. WATrs, T.: Thymus weights in malnourished children. J. Trop. Pediat., 15: 155 (1969).
44. WoOdRUFF, J. F.: The influence of quantitated post-weaning undernutrition on Coxsackievirus $\mathrm{B}_{3}$ infection of adult mice. II. Alteration of host defense mechanisms. J. Infec. Dis., 121: $164(1970)$.

45. Woodruff, J. F., and Kilbourne, E. D.: The influence of quantitated post-weaning undernutrition on Coxsackievirus $\mathrm{B}_{3}$ infection of adult mice. I. Viral persistence and increased severity of lesions. J. Infec. Dis., 121: 137 (1970).

46. Vita Vet Laboratories, Marion, Ind.

47. Startena, Purina-Ralston Company, St. Louis, Mo.

48. Sevac Laboratories, Prague, Czechoslovakia.

49. Hyland Laboratories, Los Angeles, Calif.

50. Miles Laboratories, Elkhart, Ind.

51. Pel-Freez Biological Laboratories, Rogers, Ark.

52. Haver-Lockhart, Kansas, Mo.

53. Hyland Laboratories, Costa Mesa, Calif.

54. Pharmacia, Uppsala, Sweden.

55. Nutritional Biochemical Corporation, Cleveland, Ohio.

56. Research Foundation, Chicago, Ill.

57. U.S. Department of Agriculture.

58. Bacteriological Associates, Bethesda, Md.

59. Difco, Detroit, Mich.

60. New England Nuclear, Boston, Mass.

61. Packard Instrument Company, Downers Grove, Ill.

62. Baltimore Biological, Baltimore, $\mathrm{Md}$.

63. Calbiochem, Los Angeles, Calif.

64. The authors wish to thank A. Iannetta, A. Millar, L. Moore, and T. López for their excellent technical assistance and $\mathrm{H}$. Cowen for his invaluable help and advice in handling the animals.

65. This work was supported in part by the University of Washington Graduate School Research Fund, Pediatric Microbiology Training Grant no. 5 T01 AI00227 from the Public Health Service, and Fellowship Award no. 1-F03-HD42316-01 from the National Institute of Child Health and Human Development.

66. Requests for reprints should be addressed to: Vicente López, M.D., HH627 Harborview Hospital, 325 9th Avenue, Seattle. Wash. 98104 (USA).

67. Accepted for publication May 23, 1972. 